\title{
Anion Redox Chemistry in the Cobalt Free 3d Transition Metal Oxide Intercalation Electrode $\mathrm{Li}\left[\mathrm{Li}_{0.2} \mathrm{Ni}_{0.2} \mathrm{Mn}_{0.6}\right] \mathrm{O}_{2}$
}

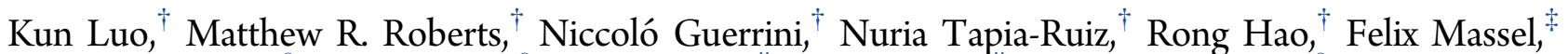
David M. Pickup, ${ }^{\S}$ Silvia Ramos, ${ }^{\S}$ Yi-Sheng Liu,, Jinghua Guo, ${ }^{\|}$Alan V. Chadwick, ${ }^{\S}$ Laurent C. Duda, and Peter G. Bruce*, ${ }^{\dagger}$

${ }^{\dagger}$ Departments of Materials and Chemistry, University of Oxford, Parks Road, Oxford OX1 3PH, United Kingdom

${ }^{\ddagger}$ Department of Physics and Astronomy, Division of Molecular and Condensed Matter Physics, Uppsala University, Box 516, S-751 20 Uppsala, Sweden

${ }^{\S}$ School of Physical Sciences, University of Kent, Canterbury, Kent CT2 7NH, United Kingdom

"Advanced Light Source, Lawrence Berkeley National Laboratory, Berkeley, California 94720, United States

\section{Supporting Information}

ABSTRACT: Conventional intercalation cathodes for lithium batteries store charge in redox reactions associated with the transition metal cations, e.g., $\mathrm{Mn}^{3+/ 4+}$ in $\mathrm{LiMn}_{2} \mathrm{O}_{4}$, and this limits the energy storage of $\mathrm{Li}$-ion batteries. Compounds such as $\mathrm{Li}\left[\mathrm{Li}_{0.2} \mathrm{Ni}_{0.2} \mathrm{Mn}_{0.6}\right] \mathrm{O}_{2}$ exhibit a capacity to store charge in excess of the transition metal redox reactions. The additional capacity occurs at and above $4.5 \mathrm{~V}$ versus $\mathrm{Li}^{+} / \mathrm{Li}$. The capacity at $4.5 \mathrm{~V}$ is dominated by oxidation of the $\mathrm{O}^{2-}$ anions accounting for $\sim 0.43 \mathrm{e}^{-}$/formula unit, with an additional 0.06 $\mathrm{e}^{-} /$formula unit being associated with $\mathrm{O}$ loss from the lattice. In contrast, the capacity above $4.5 \mathrm{~V}$ is mainly $\mathrm{O}$ loss, $\sim 0.08$ $\mathrm{e}^{-} /$formula. The $\mathrm{O}$ redox reaction involves the formation of localized hole states on $\mathrm{O}$ during charge, which are located on $\mathrm{O}$ coordinated by $\left(\mathrm{Mn}^{4+} / \mathrm{Li}^{+}\right)$. The results have been obtained by combining operando electrochemical mass spec on ${ }^{18} \mathrm{O}$ labeled $\mathrm{Li}\left[\mathrm{Li}_{0.2} \mathrm{Ni}_{0.2} \mathrm{Mn}_{0.6}\right] \mathrm{O}_{2}$ with XANES, soft X-ray spectroscopy, resonant inelastic X-ray spectroscopy, and Raman spectroscopy. Finally the general features of $\mathrm{O}$ redox are described with discussion about the role of comparatively ionic (less covalent) $3 \mathrm{~d}$ metal-oxygen interaction on anion redox in lithium rich cathode materials.

\section{INTRODUCTION}

Conventional intercalation electrodes based on oxides store electrons (charge) in redox reactions that take place on the transition metal ions. If redox reactions also occur on the oxide ions, then, in principle, lithium- ion batteries with capacities to store energy significantly greater than those currently available would be possible. Compounds such as $\mathrm{Li}\left[\mathrm{Li}_{0.2} \mathrm{Ni}_{0.13}\right.$ $\left.\mathrm{Co}_{0.13} \mathrm{Mn}_{0.54}\right] \mathrm{O}_{2}$ are known to exhibit charge storage in excess of the capacity associated with their transition metal redox chemistry. ${ }^{1}$ It is now recognized that this is, in part, due to oxide redox reactions. ${ }^{2}$ Oxygen redox chemistry has also been recognized in the $4 \mathrm{~d}$ and $5 \mathrm{~d}$ transition metal oxides, e.g., $\mathrm{Li}_{2} \mathrm{Ru}_{1-x} \mathrm{Sn}_{x} \mathrm{O}_{3}$ and $\mathrm{Li}_{2} \mathrm{IrO}_{3} .{ }^{3}$ The participation of oxygen redox processes was proposed earlier to occur in $\mathrm{LiCoO}_{2} .{ }^{4}$ The recent studies of $3 \mathrm{~d}, 4 \mathrm{~d}$, and $5 \mathrm{~d}$ transition metal oxides have illustrated the potential and importance of oxide redox chemistry. In contrast, anion redox chemistry has been known in chalcogenide chemistry for many years. ${ }^{5}$

$\mathrm{Li}\left[\mathrm{Li}_{0.2} \mathrm{Ni}_{0.2} \mathrm{Mn}_{0.6}\right] \mathrm{O}_{2}$ and $\mathrm{Li}\left[\mathrm{Li}_{0.2} \mathrm{Ni}_{0.13} \mathrm{Co}_{0.13} \mathrm{Mn}_{0.54}\right] \mathrm{O}_{2}$ are the two archetypal examples of intercalation electrodes exhibiting excess capacity. ${ }^{1 \mathrm{a}-\mathrm{c}, 2 \mathrm{a}, \mathrm{b}, 6}$ Initially, the excess capacity

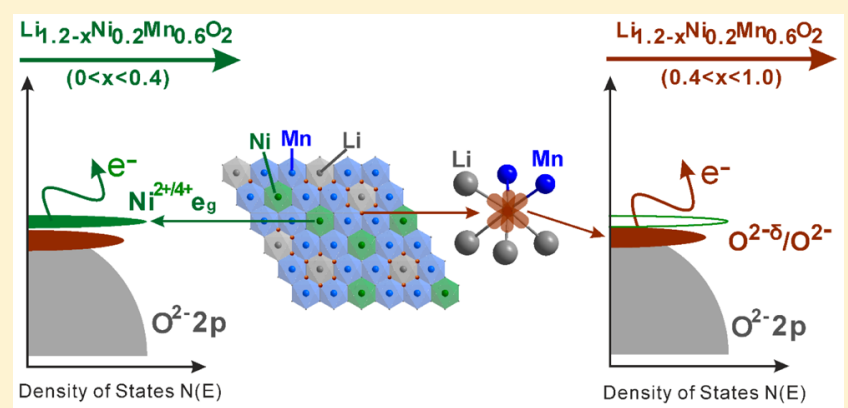

in both compounds was ascribed to oxygen loss from the lattice, in effect the loss of $\mathrm{Li}_{2} \mathrm{O}$. ${ }^{1,7}$ Recent work on $\mathrm{Li}\left[\mathrm{Li}_{0.2} \mathrm{Ni}_{0.13} \mathrm{Co}_{0.13} \mathrm{Mn}_{0.54}\right] \mathrm{O}_{2}$ has shown that $\sim 0.5 \mathrm{e}^{-}$per formula unit are stored by redox reactions on $\mathrm{O} .^{2 \mathrm{c}, 8}$ Here we investigate the nature of the excess capacity observed for the Co free $\mathrm{Li}\left[\mathrm{Li}_{0.2} \mathrm{Ni}_{0.2} \mathrm{Mn}_{0.6}\right] \mathrm{O}_{2}$ to see how it compares with $\mathrm{Li}\left[\mathrm{Li}_{0.2} \mathrm{Ni}_{0.13} \mathrm{Co}_{0.13} \mathrm{Mn}_{0.54}\right] \mathrm{O}_{2}$, using ${ }^{18} \mathrm{O}$ isotopically labeled $\mathrm{Li}\left[\mathrm{Li}_{0.2} \mathrm{Ni}_{0.2} \mathrm{Mn}_{0.6}\right] \mathrm{O}_{2}$ (which allows us to identify $\mathrm{O}$ loss form the lattice even in the absence of direct $\mathrm{O}_{2}$ gas evolution) along with operando electrochemical mass spectrometry (OEMS), soft X-ray spectroscopy (SXAS), resonant inelastic X-ray scattering (RIXS), Raman, and XANES. The excess capacity of $\mathrm{Li}\left[\mathrm{Li}_{0.2} \mathrm{Ni}_{0.2} \mathrm{Mn}_{0.6}\right] \mathrm{O}_{2}$ occurs at and above $4.5 \mathrm{~V}$ with most occurring at $4.5 \mathrm{~V}$. The capacity at $4.5 \mathrm{~V}$ is dominated by $\mathrm{O}$ redox, accounting for $\sim 0.43 \mathrm{e}^{-} /$formula unit, with only 0.06 $\mathrm{e}^{-} /$formula unit due to $\mathrm{O}$ loss. Above $4.5 \mathrm{~V}$ the excess capacity is mainly $\mathrm{O}$ loss, accounting for $\sim 0.08 \mathrm{e}^{-} /$formula unit. Oxidation of $\mathrm{O}^{2-}$ on charging is associated with the generation

Received: May 25, 2016

Published: August 8, 2016 
of localized electron holes on $\mathrm{O}$ coordinated by $\left(\mathrm{Mn}^{4+} / \mathrm{Li}^{+}\right)$. $\mathrm{Co}$, although expensive, is often included in the layered oxide cathodes because it improves kinetics and cycling stability. Understanding the origin of the excess capacity in Co free $\mathrm{Li}\left[\mathrm{Li}_{0.2} \mathrm{Ni}_{0.2} \mathrm{Mn}_{0.6}\right] \mathrm{O}_{2}$ is valuable, because it shows that the $\mathrm{O}^{2-}$ redox mechanism involving localized holes coordinated by $\left(\mathrm{Mn}^{4+} / \mathrm{Li}^{+}\right)$is not unique to Co containing cathodes but is seen in other, Co free, 3d transition metal oxides. The balance between $\mathrm{O}$ loss and $\mathrm{O}$ redox is also similar to and without $\mathrm{Co}$; hence, $\mathrm{Co}$ is not necessary in $3 \mathrm{~d}$ transition metal oxides to obtain $\mathrm{O}$ redox as the dominant process at $4.5 \mathrm{~V}$.

\section{EXPERIMENTAL SECTION}

Synthesis. $\mathrm{Li}_{1.2} \mathrm{Ni}_{0.2} \mathrm{Mn}_{0.6} \mathrm{O}_{2}$ was synthesized using a sol-gel method. ${ }^{10}$ Stoichiometric amounts of $\mathrm{LiCH}_{3} \mathrm{COO} \cdot 2 \mathrm{H}_{2} \mathrm{O}$ (99.0\%, Sigma-Aldrich), $\mathrm{Ni}\left(\mathrm{CH}_{3} \mathrm{COO}\right)_{2} \cdot 4 \mathrm{H}_{2} \mathrm{O}$ (99.0\%, Sigma-Aldrich), and $\mathrm{Mn}\left(\mathrm{CH}_{3} \mathrm{COO}\right)_{2} \cdot 4 \mathrm{H}_{2} \mathrm{O}$ (99.0\%, Fluka) were dissolved in distilled water containing $0.1 \mathrm{~mol}$ of resorcinol (99.0\%, Fluka), $0.15 \mathrm{~mol}$ of formaldehyde (Fluka $36.5 \%$ in water), and $0.25 \mathrm{mmol}$ of $\mathrm{Li}_{2} \mathrm{CO}_{3}$ (99.0\%, Sigma-Aldrich). The mixture was heated at $70^{\circ} \mathrm{C}$ for $2 \mathrm{~h}$, then at $90{ }^{\circ} \mathrm{C}$ overnight, and finally at $900{ }^{\circ} \mathrm{C}$ for $15 \mathrm{~h}$ to obtain the final material. All the procedures were carried out in air.

${ }^{18} \mathrm{O}$ labeled $\mathrm{Li}_{1.2} \mathrm{Ni}_{0.2} \mathrm{Mn}_{0.6} \mathrm{O}_{2}$ was synthesized by heating the asprepared sample described above in a mixture of $22 \%{ }^{18} \mathrm{O}_{2}$ (>95 atom $\%, 99.9 \%$ ) and $78 \% \mathrm{~N}_{2}$ (99.999\%) (BOC) at $800{ }^{\circ} \mathrm{C}$ for $8 \mathrm{~h}$. This particular gas mixture was used in order to simulate the ambient atmosphere typical for the preparation and to avoid any over oxidation.

Elemental analysis of the as-prepared sample was carried out by ion coupled plasma optical emission spectroscopy (ICP-OES) using a PerkinElmer Optima 7300DV ICP-OES.

Structural Characterization. Powder X-ray Diffraction (XRD). Powder X-ray diffraction (XRD) was carried out using a Rigaku SmartLab X-ray powder diffractometer equipped with a $9 \mathrm{~kW} \mathrm{Cu}$ rotating anode. In situ XRD data were collected using an in situ cell with an X-ray transparent beryllium window. A protective $\mathrm{Al}$ film was coated on the Be window to prevent Be oxidation at high potentials (above $4.8 \mathrm{~V} \mathrm{vs} \mathrm{Li}^{+} / \mathrm{Li}$ ). (Further information about the cell design can be obtained at www.rigaku.com.) The cell was controlled by a Biologic MPG potentiostat.

Neutron Powder Diffraction. Neutron powder diffraction data were collected using the POLARIS diffractometer at the ISIS neutron source, U.K. Rietveld profile refinements were performed using the GSAS suite of programs. ${ }^{11}$

Raman Spectroscopy. Raman spectra of the materials at different stages were collected using a Raman Renishaw InVia spectrometer equipped with a diode laser $(\lambda=785 \mathrm{~nm})$.

Hard X-ray Absorption Near Edge Structure (XANES). $\mathrm{Mn}$ and $\mathrm{Ni}$ K-edge XANES measurements were undertaken at beamline B18 at the Diamond Light Source, Harwell, U.K. This beamline covers a wide energy range $(2.05-35 \mathrm{keV})$ and is equipped with a double-crystal monochromator containing two pairs of crystals, $\mathrm{Si}(111)$ and $\mathrm{Si}(311)$, optimized for quick EXAFS (QuEXAFS) measurements. ${ }^{12}$ The spectra were collected in transmission mode with the intensities of the incident and transmitted X-ray beams measured using gas filled ionization chambers. Metal foils were placed in front of a third ionization chamber to allow the data to be corrected for any drift of the monochromator position and to permit accurate calibration of the energy scale in the XANES spectra. Two or three scans were collected for each sample. These were summed, calibrated, background subtracted, and normalized using the program Athena. ${ }^{13}$ XANES spectra were measured for $\mathrm{Mn}_{2} \mathrm{O}_{3}, \mathrm{MnO}_{2}, \mathrm{NiO}$, and $\mathrm{LiNiO}_{2}$ as reference materials.

Soft X-ray Absorption. The O K-edge soft X-ray absorption spectra (SXAS) and resonant inelastic X-ray scattering spectra (RIXS) were collected on beamline 8.0.1. at the Advanced Light Source (ALS), Lawrence Berkeley National Laboratory, USA. The beamline is equipped with a spherical grating monochromator (SGM). To obtain
SXAS spectra at the O K-edge, the total fluorescence yield (TFY) signal was recorded using a Channeltron biased for total fluorescence yield detection (in a negative potential setting to reject the photoelectrons). The O K-edge RIXS spectra were recorded using a high-resolution Rowland circle type grating spectrometer. ${ }^{14} \mathrm{~A}$ monochromator resolution of $0.2 \mathrm{eV}$ was used for recording SXAS spectra and $0.5 \mathrm{eV}$ when recording RIXS spectra, with a spectrometer resolution of $0.5 \mathrm{eV}$.

The SXAS spectra were recorded over a wide energy range from 520 to $562 \mathrm{eV}$ covering energies well below and above sample absorptions. The normalization was performed following the established procedure: ${ }^{15}$ (1) For $I_{0}$-normalization, the sample signal is divided by the incident intensity measured from the sample drain current from a freshly coated Au-mesh inserted into the beam path before the X-rays can impinge on the sample. (2) A linear, sloping background is removed by fitting a line to the flat low-energy region (from 520 to $524 \mathrm{eV}$ ) of the SXAS spectrum, i.e., at energies below any absorption peaks. (3) The spectrum is normalized by setting the flat low-energy region to zero and the postedge to unity (unit edgejump). The photon energy selected for the postedge was $560 \mathrm{eV}$, again beyond the region of any absorption (peaks), though the normalization is insensitive to the exact value since this is sufficiently above any compound-specific resonances.

Electrochemical Measurements. The working electrodes, $80 \mathrm{wt}$ $\%$ active material, $10 \mathrm{wt} \%$ Super $\mathrm{P}$ carbon, and $10 \mathrm{wt} \%$ polytetrafluoroethylene (PTFE) binder, were constructed and incorporated into electrochemical cells with a $\mathrm{Li}$ metal counter electrode and $1 \mathrm{M} \mathrm{LiPF}_{6}$ in propylene carbonate (PC) as electrolyte. The PC was distilled using a packed bed column and dried for several days over freshly activated molecular sieves (type $4 \AA$ ) prior to making up the electrolyte. Electrochemical measurements were carried out using a Biologic VMP3 potentiostat.

Operando Mass Spectrometry. Operando mass spectrometry analysis was conducted to detect the gases generated during charging and discharging. The operando mass spectrometry system was built inhouse and employed a commercial quadrupole mass spectrometer (Thermo Fischer) with a turbomolecular pump (Pfeiffer Vacuum). The setup was based on a previously described design. ${ }^{16}$ The operando mass spectrometry measurements were carried out using a Swagelok electrochemical test cell. The cell consisted of a lithium anode, electrolyte (1 $\mathrm{M} \mathrm{LiPF}_{6}$ in $\left.\mathrm{PC}\right)$, and the same cathode as described above. Calibration and quantification methods were as described in detail previously. ${ }^{17}$

TOF-SIMS Imaging. The TOF-SIMS data were collected using an ION-TOF $\mathrm{GmbH}$ instrument utilizing a $25 \mathrm{kV} \mathrm{Bi}^{3+}$ primary ion source. In order to acquire the data for this relatively large area $(250 \times$ $250 \mu \mathrm{m}^{2}$ ), a stage scanning function was employed with 20 shots per pixel and a resolution of 256 pixels $/ \mathrm{mm}$.

\section{RESULTS AND DISCUSSION}

The syntheses of $\mathrm{Li}\left[\mathrm{Li}_{0.2} \mathrm{Ni}_{0.2} \mathrm{Mn}_{0.6}\right] \mathrm{O}_{2}$, as well as the procedures used to characterize it, are described in the Experimental Section. Powder X-ray and neutron diffraction patterns, Figure S1, were collected and used to refine the structure, Table S1, confirming that the compound adopts the $\alpha-\mathrm{NaFeO}_{2}\left(\mathrm{LiCoO}_{2}\right)$ structure, composed of $\mathrm{ABC}$ stacked $\mathrm{O}^{2-}$ layers between which are alternating sheets of $\mathrm{Li}^{+}$and $\left[\mathrm{Li}_{0.2} \mathrm{Ni}_{0.2} \mathrm{Mn}_{0.6}\right]$ in octahedral sites. Additional peaks are observed in the powder X-ray diffraction pattern within the range $20-30^{\circ}$ in $2 \theta$. They are associated with short-range ordering within the octahedral cation sites of the transition metal layers occupied by $\left[\mathrm{Li}_{0.2} \mathrm{Ni}_{0.2} \mathrm{Mn}_{0.6}\right]$, in accord with previous observations. ${ }^{18}$ ICP-OES confirmed the composition of the compound was as anticipated. An SEM image of the asprepared material is shown in Figure 1. The morphology is composed of particles of $\sim 0.2-0.3 \mu \mathrm{m}$. 


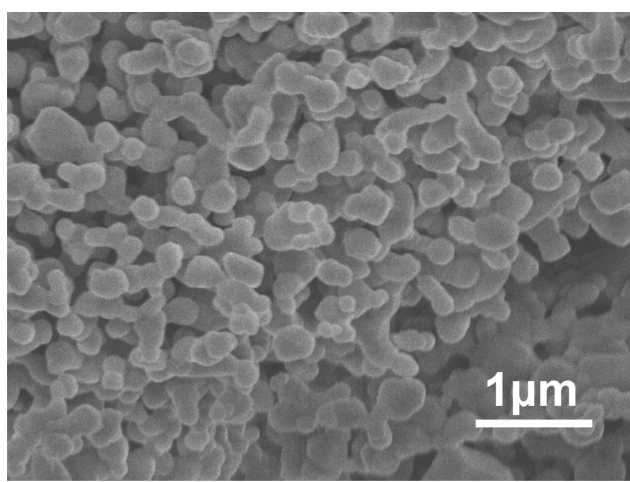

Figure 1. SEM image of as-prepared $\mathrm{Li}\left[\mathrm{Li}_{0.2} \mathrm{Ni}_{0.2} \mathrm{Mn}_{0.6}\right] \mathrm{O}_{2}$.

The variation of voltage with composition on the first charge ( $\mathrm{Li}$ extraction) and subsequent discharge ( $\mathrm{Li}$ insertion) is shown in Figure 2, and is in good agreement with previous

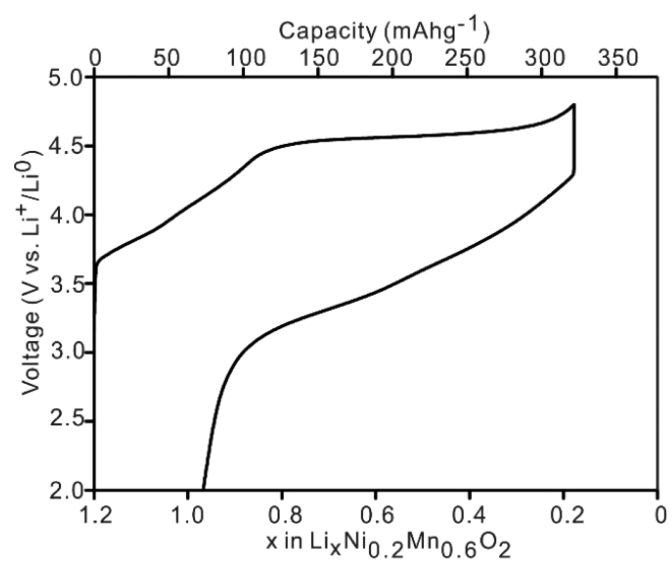

Figure 2. Voltage-composition curves for $\mathrm{Li}\left[\mathrm{Li}_{0.2} \mathrm{Ni}_{0.2} \mathrm{Mn}_{0.6}\right] \mathrm{O}_{2}$ on the 1 st cycle. (Rate $=50 \mathrm{mAg}^{-1}$.)

reports for the same material. ${ }^{1 \mathrm{a}, \mathrm{b}, \mathrm{e}, \mathrm{6}}$ Starting with the pristine material, the voltage rises continuously as $\mathrm{Li}$ is removed from the structure; this is followed by a plateau at $\sim 4.5 \mathrm{~V}$ and then an increasing potential up to $4.8 \mathrm{~V}$. In situ powder $\mathrm{X}$-ray diffraction data were collected on charge and discharge, Figure S2. The peaks shift continuously over the composition range from $x=1.2$ to 0.8 , consistent with the solid solution and the sloping voltage curve. There is limited evidence of peak shifts over the composition range from $x=0.8$ to 0.3 , in accord with the observation of a plateau in the voltage-composition curve, Figure 2, and of two-phase behavior. Beyond the end of the plateau, a shoulder appears on the (003) peak in the diffraction pattern. Similar powder diffraction patterns have been seen previously for $\mathrm{Li}\left[\mathrm{Li}_{0.2} \mathrm{Ni}_{0.2} \mathrm{Mn}_{0.6}\right] \mathrm{O}_{2}$ and $\mathrm{Li}\left[\mathrm{Li}_{0.2} \mathrm{Ni}_{0.13}\right.$ $\left.\mathrm{Co}_{0.13} \mathrm{Mn}_{0.54}\right] \mathrm{O}_{2}$ across and beyond the plateau and have been interpreted as the formation of a second phase, the lithium and oxygen deficient phase, at the surface of the particles. $^{2 b, 19}$ However, this is not the focus of the present investigation.

O Loss from the Lattice. ${ }^{18} \mathrm{O}$ labeled $\mathrm{Li}\left[\mathrm{Li}_{0.2} \mathrm{Ni}_{0.2} \mathrm{Mn}_{0.6}\right] \mathrm{O}_{2}$ was prepared by heating the as-prepared material in an atmosphere containing ${ }^{18} \mathrm{O}_{2}$, see Experimental Section for details. The percentage of ${ }^{18} \mathrm{O}$ in the resulting ${ }^{18} \mathrm{O}$ enriched $\mathrm{Li}\left[\mathrm{Li}_{0.2} \mathrm{Ni}_{0.2} \mathrm{Mn}_{0.6}\right] \mathrm{O}_{2}$ was determined by TOF-SIMS to be $15.4 \%$, see Figure S3. The ${ }^{18} \mathrm{O}$ enriched material permits identification of oxygen loss from the lattice even in the absence of direct $\mathrm{O}_{2}$ evolution. ${ }^{18} \mathrm{O} \quad \mathrm{Li}\left[\mathrm{Li}_{0.2} \mathrm{Ni}_{0.2} \mathrm{Mn}_{0.6}\right] \mathrm{O}_{2}$ was investigated by OEMS as described in the Experimental Section. The results are presented in Figure 3 and Table 1.

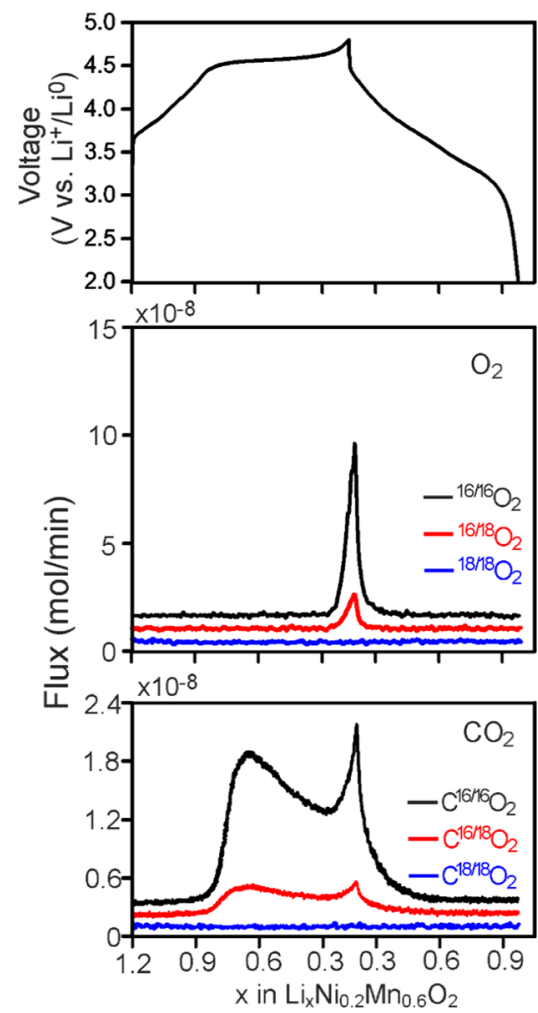

Figure 3. Operando mass spectrometry of ${ }^{18} \mathrm{O}$ labeled $\mathrm{Li}\left[\mathrm{Li}_{0.2} \mathrm{Ni}_{0.2^{-}}\right.$ $\left.\mathrm{Mn}_{0.6}\right] \mathrm{O}_{2}$ cathode during the first cycle, showing that $\mathrm{O}$ is extracted from the lattice on the $4.5 \mathrm{~V}$ plateau as well as above, despite no $\mathrm{O}_{2}$ gas being detected at $4.5 \mathrm{~V}$. The three plots for $\mathrm{O}_{2}$ and $\mathrm{CO}_{2}$ are displaced in the $y$-direction for clarity.

Table 1. Predicted ${ }^{a}$ and Experimental Percentages for Gases Evolved from ${ }^{18} \mathrm{O}$ Labeled $\mathrm{Li}\left[\mathrm{Li}_{0.2} \mathrm{Ni}_{0.2} \mathrm{Mn}_{0.6}\right] \mathrm{O}_{2}$ During the First Charge

\begin{tabular}{|c|c|c|c|}
\hline \multirow{2}{*}{$\begin{array}{c}\text { gas } \\
\text { evolution }\end{array}$} & \multirow{2}{*}{$\begin{array}{l}\text { predicted } \\
\text { percentage }\end{array}$} & \multicolumn{2}{|c|}{ experimental percentage } \\
\hline & & $\begin{array}{c}\text { across the } \\
4.5 \mathrm{~V} \text { plateau }\end{array}$ & $\begin{array}{l}\text { beyond the } \\
4.5 \mathrm{~V} \text { plateau }\end{array}$ \\
\hline & & $\mathrm{O}_{2}$ & \\
\hline${ }^{16 / 16} \mathrm{O}_{2}$ & $72 \%$ & & $80 \%$ \\
\hline${ }^{16 / 18} \mathrm{O}_{2}$ & $26 \%$ & none & $20 \%$ \\
\hline${ }^{18 / 18} \mathrm{O}_{2}$ & $2 \%$ & & 0 \\
\hline & & $\mathrm{CO}_{2}$ & \\
\hline $\mathrm{C}^{16 / 16} \mathrm{O}_{2}$ & $79 \%$ & $87 \%$ & $88 \%$ \\
\hline $\mathrm{C}^{16 / 18} \mathrm{O}_{2}$ & $20 \%$ & $13 \%$ & $12 \%$ \\
\hline $\mathrm{C}^{16 / 18} \mathrm{O}_{2}$ & $1 \%$ & 0 & 0 \\
\hline
\end{tabular}

${ }^{a}$ From reactions between reduced oxygen species and carbonate electrolytes, scheme shown in Supporting Information.

No gas evolution was observed on charging the pristine ${ }^{18} \mathrm{O}$ enriched material up to the beginning of the $4.5 \mathrm{~V}$ plateau, Figure 3. On charging across the $4.5 \mathrm{~V}$ plateau, only $\mathrm{CO}_{2}$ was detected, Figure 3; i.e., no direct $\mathrm{O}_{2}$ evolution was observed. The $\mathrm{CO}_{2}$ contained $\mathrm{C}^{16 / 18} \mathrm{O}_{2}$, demonstrating that, despite the absence of any direct oxygen gas evolution, $\mathrm{O}$ is extracted from the lattice on charging at $4.5 \mathrm{~V}$ and reacts with the electrolyte to form $\mathrm{CO}_{2}$. At potentials above the plateau, $\mathrm{CO}_{2}$ and $\mathrm{O}_{2}$ gases 
were detected, both containing the ${ }^{18} \mathrm{O}$ isotope, showing that oxygen continues to be extracted from the lattice up to the cutoff potential of $4.8 \mathrm{~V}$. Our previous investigation of $\mathrm{LiNi}_{0.5} \mathrm{Mn}_{1.5} \mathrm{O}_{4}$ spinel charged in the same electrolyte to 4.8 $\mathrm{V}$, which is not expected to exhibit oxygen loss, showed that the quantity of $\mathrm{CO}_{2}$ and $\mathrm{O}_{2}$ is less than $1 \%$ of that observed for the layered $\mathrm{Li}\left[\mathrm{Li}_{0.2} \mathrm{Ni}_{0.2} \mathrm{Mn}_{0.6}\right] \mathrm{O}_{2}$ material, indicating that the gas evolution observed for $\mathrm{Li}\left[\mathrm{Li}_{0.2} \mathrm{Ni}_{0.2} \mathrm{Mn}_{0.6}\right] \mathrm{O}_{2}$ is associated primarily with $\mathrm{O}$ loss from the lattice and not direct oxidation of the electrolyte. ${ }^{2 c}$

The reaction of reduced $\mathrm{O}$ species with organic carbonatebased electrolyte solutions, such as is used here, has been investigated in the context of the $\mathrm{Li}-\mathrm{O}_{2}$ battery. ${ }^{20}$ The reaction scheme is shown in the Supporting Information and involves a ring opening of the $\mathrm{PC}$ electrolyte, which is followed by oxidation of the resulting product to $\mathrm{CO}_{2}$. On the basis of this scheme, the reactive oxygen species extracted from the lattice attacks the organic carbonate electrolyte solution producing $\mathrm{CO}_{2}$ that will contain ${ }^{18} \mathrm{O}$ from the lattice, but also additional $\mathrm{CO}_{2}$ containing $\mathrm{O}$ derived from the solvent. By analyzing the quantity of the various $\mathrm{CO}_{2}$ isotopes involved, and knowing the ${ }^{18} \mathrm{O} /{ }^{16} \mathrm{O}$ ratio in the isotopically enriched $\mathrm{Li}\left[\mathrm{Li}_{0.2} \mathrm{Ni}_{0.2} \mathrm{Mn}_{0.6}\right] \mathrm{O}_{2}$, the amount of charge extracted across the plateau at $4.5 \mathrm{~V}$ associated with $\mathrm{O}$ loss can be estimated, see SI for details. The value of $0.06 \mathrm{e}^{-}$/formula unit is obtained for $\mathrm{O}$ loss at $4.5 \mathrm{~V}$. The proportions of $\mathrm{C}^{16 / 16} \mathrm{O}_{2}$ and $\mathrm{C}^{16 / 18} \mathrm{O}_{2}$ observed are, respectively, somewhat higher and lower than predicted from the ${ }^{16 / 18} \mathrm{O}$ in the lattice, Table 1 . This is to be expected, due in part to the TOF-SIMS detecting the ${ }^{18} \mathrm{O} /{ }^{16} \mathrm{O}$ ratio at or very near the surface, and therefore we can anticipate less ${ }^{18} \mathrm{O}$ as we progress deeper into the sample during charging. Beyond the $4.5 \mathrm{~V}$ plateau, the $\mathrm{CO}_{2}$ accounts for $0.03 \mathrm{e}^{-} /$formula unit. The ratio of 18 to $16 \mathrm{O}$ isotopes in the $\mathrm{O}_{2}$ gas that evolved beyond the plateau is very close to that in the material, indicating that all the $\mathrm{O}_{2}$ gas is generated from $\mathrm{O}$ extracted from the lattice and accounts for $0.05 \mathrm{e}^{-} /$formula unit. Taking both the $\mathrm{CO}_{2}$ and $\mathrm{O}_{2}$ evolved above $4.5 \mathrm{~V}$ into account gives a total charge extracted associated with $\mathrm{O}$ loss from the lattice above $4.5 \mathrm{~V}$ of $0.08 \mathrm{e}^{-}$ /formula unit.

The majority of the charge extracted above $4.5 \mathrm{~V}$ is associated with oxygen loss from the lattice. In contrast, oxygen loss accounts for only a minority of the charge extracted across the $4.5 \mathrm{~V}$ plateau. The balance of this charge is attributed to the creation of electron holes on the oxide ions in the lattice, as discussed in the subsequent section. It has been proposed that the oxygen loss leads to the formation of a surface phase. $^{2 b, 19}$ Therefore, it is very likely that the oxygen loss observed in our OEMS experiment occurs mainly near the surface of the particles.

Holes on O. XANES spectra for the Ni- and $\mathrm{Mn}-\mathrm{K}$ edges of $\mathrm{Li}\left[\mathrm{Li}_{0.2} \mathrm{Ni}_{0.2} \mathrm{Mn}_{0.6}\right] \mathrm{O}_{2}$, collected as a function of the state of charge, are shown in Figure 4. The Ni XANES spectra demonstrate an increase in oxidation state consistent with $\mathrm{Ni}^{2+}$ oxidation toward $\mathrm{Ni}^{4+}$ on charging the pristine material up to the beginning of the $4.5 \mathrm{~V}$ plateau. Thereafter, no further change in the Ni XANES spectra was observed. It should be noted that a small degree of shifting back toward lower energies for the $\mathrm{Ni}$ edge is seen on the $4.5 \mathrm{~V}$ plateau; this has been observed by Croguennec and co-workers and interpreted by them as migration of some $\mathrm{Ni}$ from the slab to the interslab space within the structure. ${ }^{2 a}$ For $\mathrm{Mn}$ it is the pre-edge that provides the most reliable signature for the oxidation state. ${ }^{2 a, 21}$ Throughout the entire charging regime there are negligible
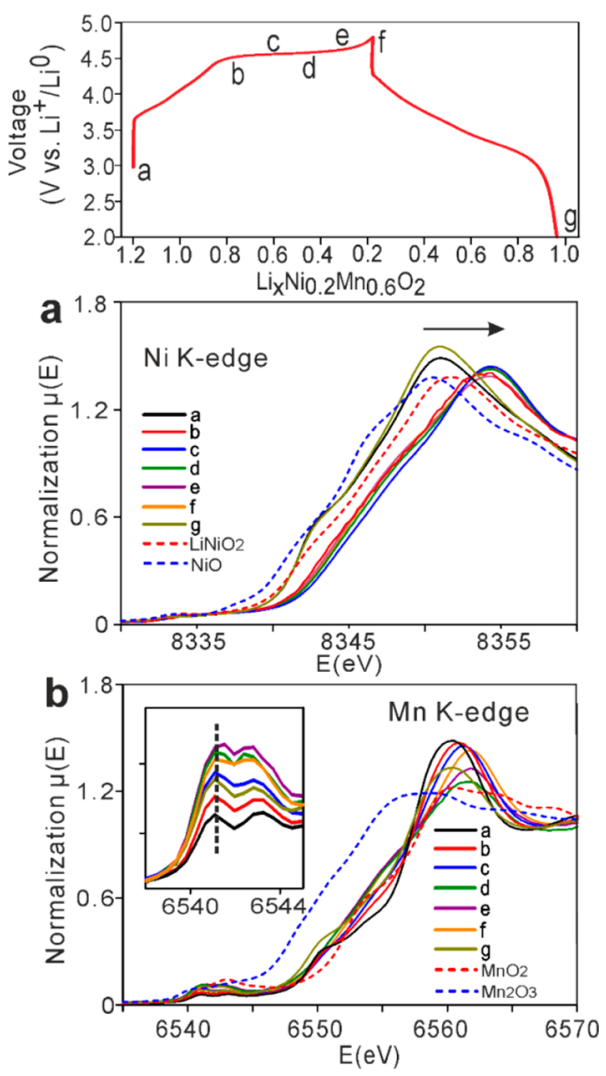

Figure 4. Evolution of the (a) Ni and (b) Mn K-edge XANES spectra for $\mathrm{Li}\left[\mathrm{Li}_{0.2} \mathrm{Ni}_{0.2} \mathrm{Mn}_{0.6}\right] \mathrm{O}_{2}$ on charge and subsequent discharge. Preedge for Mn shown as an inset to part $b$.

shifts in the Mn pre-edge spectra (the inset in Figure $4 \mathrm{~b}$ ), indicating no change in the $\mathrm{Mn}^{4+}$ oxidation state. The $\mathrm{Ni}$ and Mn XANES spectra and their interpretation are consistent with previous results. $^{2 \mathrm{a}, \mathrm{c}}$ The additional capacity to oxidize this material is not associated with further oxidation of the transition metal ions, but with oxidation of the oxide anions.

Soft X-ray spectra, corresponding to transitions from the $\mathrm{O}$ $1 \mathrm{~s}$ to the empty states above the Fermi level, were collected on charging $\mathrm{Li}\left[\mathrm{Li}_{0.2} \mathrm{Ni}_{0.2} \mathrm{Mn}_{0.6}\right] \mathrm{O}_{2}$ and are shown in Figure 5a. The spectra effectively probe the density of hole states above the Fermi level. The spectrum of the pristine material is dominated by transitions from the $\mathrm{O} 1 \mathrm{~s}$ to empty states on the $\mathrm{Mn}^{4+}$ mixed with $\mathrm{O} 2 \mathrm{p}$ orbitals, as this is the dominant transition metal ion in the compound and accounts for $91 \%$ of the spectral transitions, see SI for details. As a result, the spectrum resembles that for $\mathrm{MnO}_{2}$, Figure 5a. Integration of the soft Xray spectra between 525 and $534 \mathrm{eV}$ reflects the density of hole states just above the Fermi level. ${ }^{2 c, 22}$ The transitions above this energy are to the transition metal $4 \mathrm{sp}$ band mixed with $\mathrm{O} 2 \mathrm{p}$ states. The integrated intensity relative to that of the pristine material is shown in Figure $5 b$ and is a measure of the increased density of hole states just above the Fermi level. Initially, on charging the material to the beginning of the plateau, an increase in the density of hole states of $8.7 \%$ is observed which compares well with the $8.2 \%$ increase expected from the removal of $0.4 \mathrm{e}^{-} /$formula unit through the oxidation of $\mathrm{Ni}^{2+}$ in $\mathrm{Li}\left[\mathrm{Li}_{0.2} \mathrm{Ni}_{0.2} \mathrm{Mn}_{0.6}\right] \mathrm{O}_{2}$. From the soft X-ray spectra, the density of hole states increases across the plateau by a further $8.5 \%$ corresponding to the extraction of $0.43 \mathrm{e}^{-} /$formula unit. In a combination with the charge extracted due to $\mathrm{O}$ loss across the plateau estimated from the OEMS measurement, $0.06 \mathrm{e}^{-} /$ 

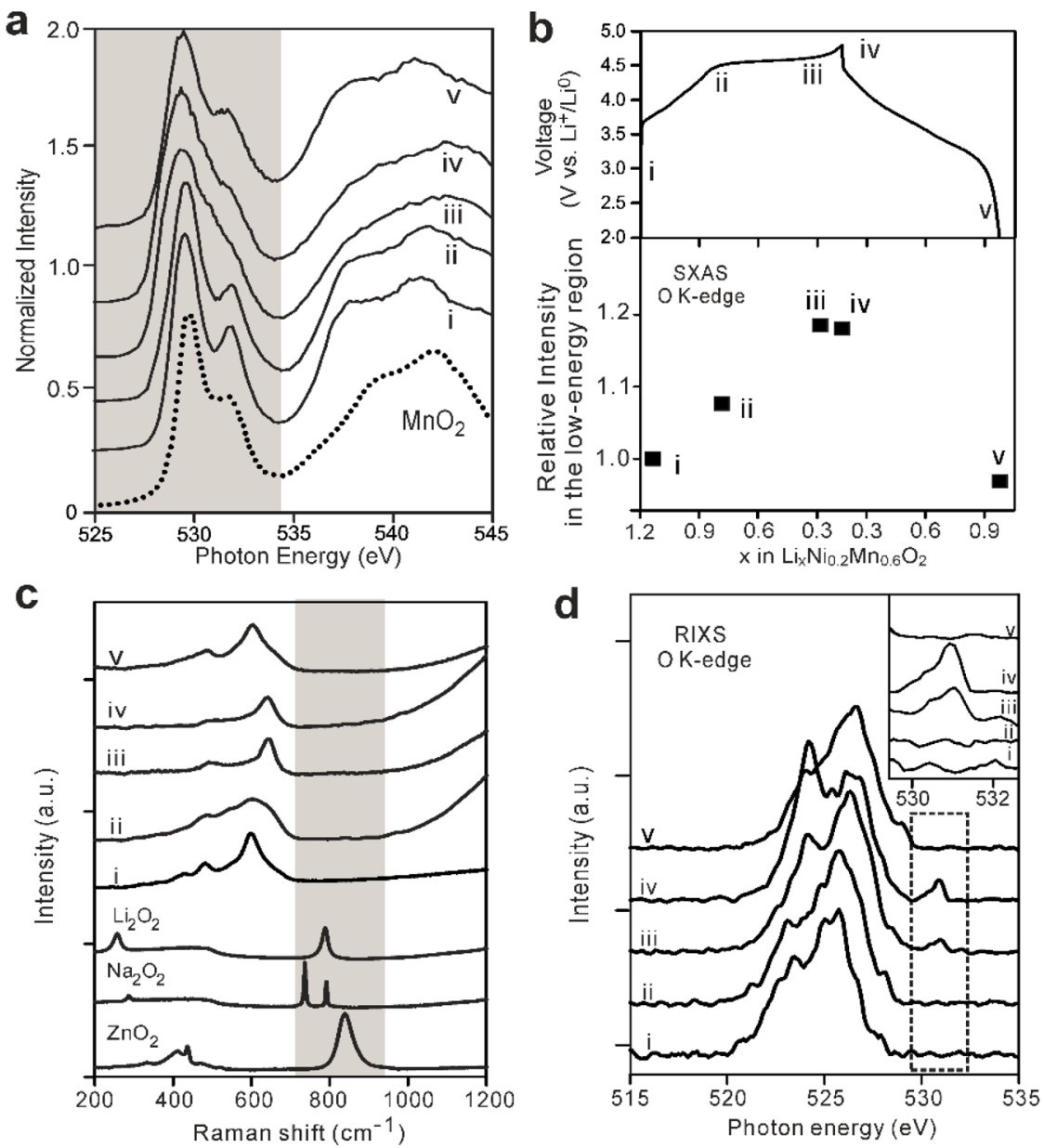

Figure 5. Nature of electron holes on oxygen. (a) SXAS spectra collected at different states of charge in total fluorescence yield (TFY) mode, and corresponding to the points on the load curve in part b. (b) Variation of the relative integrated intensity in the low-energy region (shaded region in a) for O K-edge SXAS at the points shown in the load curve immediately above. (c) Raman spectra at different states of charge. The gray shading indicates the region of $\mathrm{O}-\mathrm{O}$ vibrations for the three reference samples. (d) O K-edge RIXS spectra with an excitation energy of $531.5 \mathrm{eV}$.

formula unit, the sum, $0.49 \mathrm{e}^{-} /$formula unit, is close to the total charge extracted at $4.5 \mathrm{~V}, 0.52 \mathrm{e}^{-} /$formula unit. Beyond $4.5 \mathrm{~V}$ the soft X-ray spectra show there is little evidence that additional hole states are created, confirming that the dominant mechanism of charging above $4.5 \mathrm{~V}$ involves $\mathrm{O}$ loss from the lattice, as noted above in the OEMS section. On the basis of the total charge passed on charging, $\sim 1.02 \mathrm{e}^{-} /$formula unit of charge is extracted; this compares well with the $0.97 \mathrm{e}^{-} /$formula unit accounted for from $\mathrm{Ni}$ oxidation $\left(0.4 \mathrm{e}^{-} /\right.$formula unit), electron holes on the oxygen ( $0.43 \mathrm{e}^{-} /$formula unit), and oxygen loss ( $0.14 \mathrm{e}^{-} /$formula unit).

In sulfides, $S$ redox chemistry is known to involve $S_{2}{ }^{2-}$ species. ${ }^{5 \mathrm{a}, \mathrm{b}}$ There is little evidence for the formation of true $\mathrm{O}_{2}{ }^{2-}$ peroxide (O-O $1.45 \AA$ ) in the bulk of $\mathrm{Li}\left[\mathrm{Li}_{0.2} \mathrm{Ni}_{0.2} \mathrm{Mn}_{0.6}\right]$ $\mathrm{O}_{2}$ at $4.5 \mathrm{~V}$ or above up to $4.8 \mathrm{~V}$. Raman spectra collected as a function of the state of charge, Figure 5c, are compared with several compounds known to contain $\mathrm{O}_{2}{ }^{2-}$ species. No bands are apparent in the $\mathrm{O}_{2}{ }^{2-}$ region for $\mathrm{Li}\left[\mathrm{Li}_{0.2} \mathrm{Ni}_{0.2} \mathrm{Mn}_{0.6}\right] \mathrm{O}_{2}$ at any state of charge. However, no conclusions can be drawn as to the formation of $\mathrm{O}_{2}{ }^{n-}$ species with bond lengths significantly longer than $1.45 \AA$ (e.g., $2.45 \AA$ ) as has been proposed in the case of $4 \mathrm{~d}$ and $5 \mathrm{~d}$ transition metal oxides. ${ }^{3}$

To probe further the nature of the hole states on $\mathrm{O}, \mathrm{O} \mathrm{K}$ edge RIXS spectra were collected as a function of the state of charge; the data are presented in Figure 5d. RIXS detects the emission between the $\mathrm{O} 2 \mathrm{p}$ valence band below the Fermi level and the $\mathrm{O}$ 1s energy level. The spectral weight in the range from 520 to $530 \mathrm{eV}$ remains almost unchanged from point $\mathrm{i}$ to ii, confirming that little participation of oxygen occurs in this region, consistent with our analysis of the SXAS data above. Significant changes are observed across the plateau at $4.5 \mathrm{~V}$ with the elastic peak at $531.5 \mathrm{eV}$ growing in intensity. The growing elastic peak indicates that electron-hole states with a localized character are created on the oxygens. Concomitantly, a change in spectral weight is observed between iii and iv in Figure $5 \mathrm{~d}$, indicating a redistribution of the density of states in the $\mathrm{O} 2 \mathrm{p}$ band. The Mn XANES spectra exhibit a variation in the $1 \mathrm{~s}-4 \mathrm{p}$ peak energies on charging at and above $4.5 \mathrm{~V}$ (Figures 4 and 6), indicating a change in the immediate environment around $\mathrm{Mn}$ (e.g., distortion of the $\mathrm{MnO}_{6}$ octahedra). ${ }^{2 a, 21,23}$ No such change is evident in the $\mathrm{Ni}$ XANES, Figure 6. These results suggest that the localized holes on oxygen generated at $4.5 \mathrm{~V}$ are coordinated by $\mathrm{Mn}^{4+}$.

$\mathrm{Li}\left[\mathrm{Li}_{0.2} \mathrm{Ni}_{0.2} \mathrm{Mn}_{0.6}\right] \mathrm{O}_{2}$ is derived from $\mathrm{Li}_{2} \mathrm{MnO}_{3}$, which may be written as $\mathrm{Li}\left[\mathrm{Li}_{1 / 3} \mathrm{Mn}_{2 / 3}\right] \mathrm{O}_{2}$ emphasizing the layered, $\mathrm{LiCoO}_{2}$, structure, with $\mathrm{Li}$ layers and $\left[\mathrm{Li}_{1 / 3} \mathrm{Mn}_{2 / 3}\right]$ layers, Figure 7a. The substitution $\mathrm{Li}\left[\mathrm{Li}_{1 / 3-2 x / 3} \mathrm{Mn}_{2 / 3-x / 3} \mathrm{Ni}_{x}\right] \mathrm{O}_{2}$ for $x$ $=0.2$ results in the composition of the material studied here. The transition metal layers in $\mathrm{Li}\left[\mathrm{Li}_{1 / 3} \mathrm{Mn}_{2 / 3}\right] \mathrm{O}_{2}$ exhibit shortrange ordering of the $\mathrm{Li}^{+}$and $\mathrm{Mn}^{4+}$ forming a honeycomb 


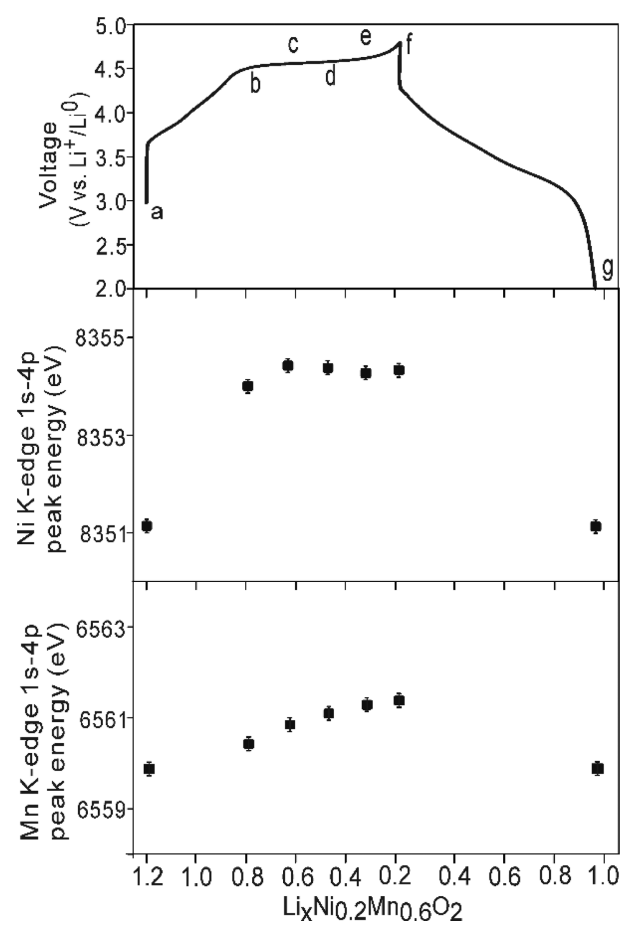

Figure 6. $1 \mathrm{~s}-4 \mathrm{p}$ peak energy of $\mathrm{Ni}$ and $\mathrm{Mn}$ K-edge XANES spectra during the first cycle, showing almost no change in the environment around $\mathrm{Ni}$, but a change in the environment around $\mathrm{Mn}$ on charging across the $4.5 \mathrm{~V}$ plateau.

structure. ${ }^{24}$ Although the atomic arrangement is not known in detail, the honeycomb short-range order persists in the $\mathrm{Li}\left[\mathrm{Li}_{0.2} \mathrm{Ni}_{0.2} \mathrm{Mn}_{0.6}\right] \mathrm{O}_{2}$ compound, as is evident in the powder $\mathrm{X}$-ray diffraction pattern in Figure S1, which exhibits peaks in the range $20-30^{\circ}$ in $2 \theta$ associated with the honeycomb ordering demonstrated previously, ${ }^{18 a, b, 25}$ shown in Figure $7 \mathrm{c}$.
The ordering arises from the differences in size and charge of the cations on the octahedral sites in the transition metal layers. Each $\mathrm{O}^{2-}$ in $\mathrm{Li}\left[\mathrm{Li}_{0.2} \mathrm{Ni}_{0.2} \mathrm{Mn}_{0.6}\right] \mathrm{O}_{2}$ is surrounded by six cations in an octahedral arrangement, three $\mathrm{Li}^{+}$ions from the alkali metal layers and three cations from the transition metal layers, Figure $7 \mathrm{~b}$. As a consequence of the ordering of the cations in the transition metal layers, not all the $\mathrm{O}^{2-}$ ions are equal; they are in different cation coordination environments. A proportion of them will be coordinated by $\left(\mathrm{Mn}^{4+} / \mathrm{Li}^{+}\right)$cations only, rather than $\mathrm{Ni}^{2+} / \mathrm{Mn}^{4+}$ or $\mathrm{Ni}^{2+} / \mathrm{Mn}^{4+} / \mathrm{Li}^{+}$, Figure $7 \mathrm{c}$. It is these $\mathrm{O}^{2-}$ ions that are expected to accommodate the localized holes, consistent with changes in the Mn XANES but not in the equivalent $\mathrm{Ni}$ spectra. It should be noted that, based on the honeycomb structure with the relative proportions of $\mathrm{Ni}, \mathrm{Mn}$, and $\mathrm{Li}$ in the transition metal layers, the available number of sites for $\mathrm{O}$ ions coordinated only by $\mathrm{Mn}^{4+} / \mathrm{Li}^{+}$could yield the formation of up to $\sim 0.8$ holes per formula unit.

Comparing Co free $\mathrm{Li}\left[\mathrm{Li}_{0.2} \mathrm{Ni}_{0.2} \mathrm{Mn}_{0.6}\right] \mathrm{O}_{2}$ with Co containing $\mathrm{Li}\left[\mathrm{Li}_{0.2} \mathrm{Ni}_{0.13} \mathrm{Co}_{0.13} \mathrm{Mn}_{0.54}\right] \mathrm{O}_{2},{ }^{8}$ the excess capacity in both arises mainly from redox reactions on the $\mathrm{O}^{2-}$ ions involving localized holes on $\mathrm{O}$ coordinated by $\left(\mathrm{Mn}^{4+} / \mathrm{Li}^{+}\right)$. Both also involve some O loss, especially above $4.5 \mathrm{~V}$. The lack of Co does not change significantly the nature of the excess capacity.

Redox Chemistry of Oxygen. The processes accompanying lithium extraction from $\mathrm{Li}\left[\mathrm{Li}_{0.2} \mathrm{Ni}_{0.2} \mathrm{Mn}_{0.6}\right] \mathrm{O}_{2}$ can now be summarized. Initially, on charging, electrons are removed from the $\mathrm{e}_{\mathrm{g}}$ states of the octahedrally coordinated $\mathrm{Ni}^{2+}\left(\mathrm{t}_{2 \mathrm{~g}}{ }^{6} \mathrm{e}_{\mathrm{g}}{ }^{2}\right)$, as these are the highest occupied states at the Fermi level, Figure $7 \mathrm{~d}$. As $\mathrm{Ni}^{2+}$ is oxidized toward $\mathrm{Ni}^{4+}\left(\mathrm{t}_{2 \mathrm{~g}}{ }^{6} \mathrm{e}_{\mathrm{g}}{ }^{0}\right)$, the energy of the $e_{g}$ orbitals drops and approaches the top of the oxygen valence band. At the same time, the energy of the oxygen valence band increases due to the removal of $\mathrm{Li}^{+}$from the lattice. ${ }^{26}$ Oxidation beyond $\mathrm{Ni}^{4+}$ would involve removal of electrons from the $\mathrm{t}_{2 \mathrm{~g}}{ }^{6}$ manifold; the associated $\mathrm{Ni}^{4+/ 5+}$ redox couple would lie below the top of the oxygen valence band and is therefore not

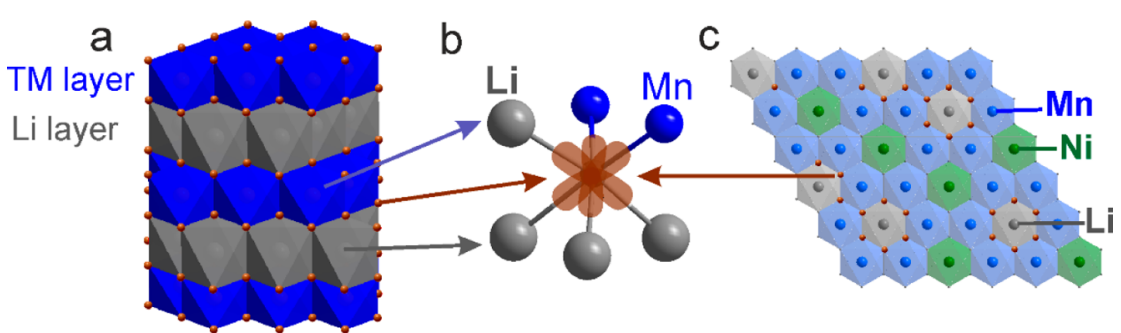

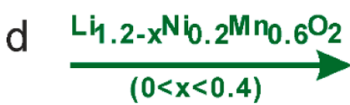

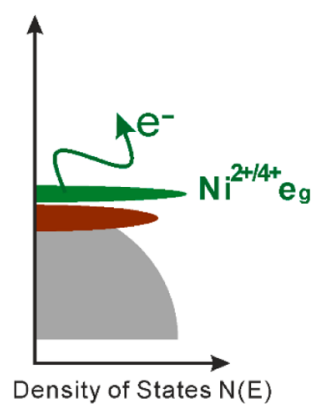

e

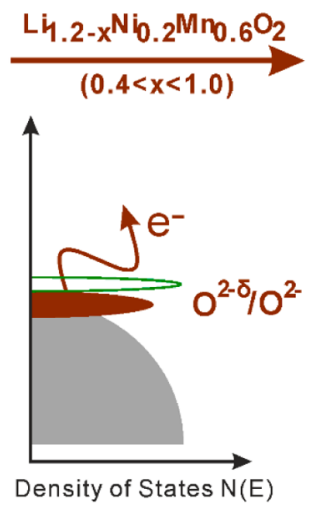

Figure 7. (a) Layered structure of $\mathrm{Li}\left[\mathrm{Li}_{0.2} \mathrm{Ni}_{0.2} \mathrm{Mn}_{0.6}\right] \mathrm{O}_{2}$, (b) coordination around $\mathrm{O}^{2-}$, (c) honeycomb cation ordering in $\mathrm{TM}$ layer of $\mathrm{Li}\left[\mathrm{Li}_{0.2} \mathrm{Ni}_{0.2} \mathrm{Mn}_{0.6}\right] \mathrm{O}_{2}$ and $\mathrm{O}^{2-}$ ions coordinated by $\left(\mathrm{Mn}^{4+} / \mathrm{Li}^{+}\right)$, (d) schematic representation of the density of states $(\mathrm{DOS})$ of $\mathrm{Li}^{2}\left[\mathrm{Li}_{0.2} \mathrm{Ni}_{0.2} \mathrm{Mn}_{0.6}\right] \mathrm{O}_{2}$ summarizing the conclusions from our spectroscopic studies, (e) representation as for part $\mathrm{d}$ but at the beginning of the $4.5 \mathrm{~V}$ plateau. 
accessed. This is also the case for the $\mathrm{Mn}^{4+/ 5+}$ redox couple. As a result, further lithium extraction is associated with the creation of holes on the oxygens, Figure 7e. Focusing on the oxygens, they are coordinated by $3 \mathrm{Li}^{+}$from the layer below and $3\left[\mathrm{Li}_{0.2} \mathrm{Ni}_{0.2} \mathrm{Mn}_{0.6}\right]$ from the layer above, Figure $7 \mathrm{~b}$. The $\mathrm{O}$ $2 \mathrm{p}$ orbitals point toward the cations coordinating $\mathrm{O}^{2-}$, Figure 7b. $\sigma^{*}$ overlap will occur with the $\mathrm{e}_{\mathrm{g}}$ states of the transition metal ions. Since the $\mathrm{e}_{\mathrm{g}}$ states of $\mathrm{Ni}^{4+}$ are expected to be lower in energy than those of $\mathrm{Mn}^{4+}$, and close to the top of the oxygen valence band, relatively strong $\mathrm{O} 2 \mathrm{p}-\mathrm{Ni}^{4+} \mathrm{e}_{\mathrm{g}}$ mixing (strong covalency) is anticipated. As a result, the $\mathrm{O} 2 \mathrm{p}$ states bonded to $\mathrm{Ni}^{4+}$ will lie lower in energy than those bonded to $\mathrm{Mn}^{4+}$ (less covalent). The $\mathrm{O} 2 \mathrm{p}-\mathrm{Li}^{+} 2 \mathrm{~s}$ interactions are also relatively ionic. As noted above, the $\left[\mathrm{Li}_{0.2} \mathrm{Ni}_{0.2} \mathrm{Mn}_{0.6}\right]$ cations in the transition metal layers exhibit short-range order resulting in different $\mathrm{O}^{2-}$ coordination environments. We anticipate that the $\mathrm{O}^{2-}$ ions coordinated by $\left(\mathrm{Mn}^{4+} / \mathrm{Li}^{+}\right)$will be associated with $\mathrm{O} 2 \mathrm{p}$ states near the top of the $\mathrm{O}$ valence band due to the relatively ionic $\mathrm{O}^{2-}-\left(\mathrm{Mn}^{4+} / \mathrm{Li}^{+}\right)$interactions. Such ionic bonding also serves to localize the $\mathrm{O} 2 \mathrm{p}$ states into a narrow band, Figure 7 d,e. These are the states from which electrons will be removed, i.e., the $\mathrm{O}$ redox states, on charging beyond the limit of transition metal oxidation.

On the basis of the results for $\mathrm{Li}\left[\mathrm{Li}_{0.2} \mathrm{Ni}_{0.2} \mathrm{Mn}_{0.6}\right] \mathrm{O}_{2}$ and our previous studies of $\mathrm{Li}\left[\mathrm{Li}_{0.2} \mathrm{Ni}_{0.13} \mathrm{Co}_{0.13} \mathrm{Mn}_{0.54}\right] \mathrm{O}_{2}$, the general feature that emerges for $3 \mathrm{~d}$ transition metal oxides is $\mathrm{O}$ redox which is usually associated with $\mathrm{O}^{2-}$ ions coordinated by cations such as $\mathrm{Li}^{+}$and $\mathrm{Mn}^{4+}$, since these form relatively ionic interactions between the $\mathrm{O} 2 \mathrm{p}$ and $2 \mathrm{~s}$ and $3 \mathrm{~d}$ orbitals of the cations, respectively. Hence, $\mathrm{O}$ redox is often observed in compounds that contain high proportions of these cations. Such ionic interactions also assist in placing the $\mathrm{O}$ redox states at an energy and hence voltage that are accessible with established organic electrolytes $(<4.7 \mathrm{~V})$. As a result of holes on $\mathrm{O}^{2-}$, especially if they are relatively localized due to ionic bonding to the neighboring cations, the $\mathrm{O}$ ions are likely to be less stable in the lattice, resulting in $\mathrm{O}$ loss competing with reversible $\mathrm{O}$ redox. To take advantage of the latter as a means of increasing practical capacity to store charge it is necessary to suppress the former.

\section{CONCLUSION}

Investigation of the lithium intercalation cathode $\mathrm{Li}$ $\left[\mathrm{Li}_{0.2} \mathrm{Ni}_{0.2} \mathrm{Mn}_{0.6}\right] \mathrm{O}_{2}$, using a range of techniques, demonstrates that $0.43 \mathrm{e}^{-} /$formula unit are extracted on charging across the $4.5 \mathrm{~V}$ plateau as a result of oxidation of the $\mathrm{O}^{2-}$ ions; a further $0.06 \mathrm{e}^{-} /$formula unit is associated with $\mathrm{O}$ loss from the lattice. The electron-holes created on $\mathrm{O}^{2-}$ oxidation are localized on O coordinated by $\left(\mathrm{Mn}^{4+} / \mathrm{Li}^{+}\right)$. The relatively ionic (weakly covalent) $\mathrm{O}-\left(\mathrm{Mn}^{4+} / \mathrm{Li}^{+}\right)$interactions promote the electronhole localization and locate the hole states near to the top of the oxygen valence band. The subtle balance between $\mathrm{O}^{2-}$ redox reactions and $\mathrm{O}$ loss, demonstrated by these results, sets the challenge for stabilizing the former over the latter in attempts to access increased reversible charge storage capacity in intercalation cathodes utilizing both transition metal and oxygen redox reactions.

\section{ASSOCIATED CONTENT}

\section{S Supporting Information}

The Supporting Information is available free of charge on the ACS Publications website at DOI: 10.1021/jacs.6b05111.
Extended characterization results, including XRD, neutron diffraction data, in situ XRD, and TOF-SIMS data (PDF)

\section{AUTHOR INFORMATION}

\section{Corresponding Author}

*peter.bruce@materials.ox.ac.uk

\section{Notes}

The authors declare no competing financial interest.

\section{ACKNOWLEDGMENTS}

P.G.B. is indebted to the EPSRC, including the SUPREGEN program, for financial support. L.C.D. thankfully acknowledges financial support from Swedish Research Council (VR). A.V.C. thanks Diamond Light Source for the award of beam time as part of the Energy Materials Block Allocation Group SP14239. The Advanced Light Source is supported by the Director, Office of Science, Office of Basic Energy Sciences, US Department of Energy, under Contract No. DE-AC0205CH11231. The authors are also grateful to Ron Smith for the collection of neutron diffraction data and G. Cibin for the collection of hard XAS data. Please find Oxford University Research Archive (ORA) deposit at DOI: 10.5287/bodleian:aZAGnEAoN.

\section{REFERENCES}

(1) (a) Lu, Z. H.; Dahn, J. R. J. Electrochem. Soc. 2002, 149 (7), A815-A822. (b) Lu, Z. H.; MacNeil, D. D.; Dahn, J. R. Electrochem. Solid-State Lett. 2001, 4 (11), A191-A194. (c) Johnson, C. S.; Kim, J. S.; Lefief, C.; Li, N.; Vaughey, J. T.; Thackeray, M. M. Electrochem. Commun. 2004, 6 (10), 1085-1091. (d) Thackeray, M. M.; Johnson, C. S.; Vaughey, J. T.; Li, N.; Hackney, S. A. J. Mater. Chem. 2005, 15 (23), 2257-2267. (e) Thackeray, M. M.; Kang, S. H.; Johnson, C. S.; Vaughey, J. T.; Benedek, R.; Hackney, S. A. J. Mater. Chem. 2007, 17 (30), 3112-3125.

(2) (a) Koga, H.; Croguennec, L.; Menetrier, M.; Mannessiez, P.; Weill, F.; Delmas, C.; Belin, S. J. Phys. Chem. C 2014, 118 (11), 57005709. (b) Koga, H.; Croguennec, L.; Menetrier, M.; Mannessiez, P.; Weill, F.; Delmas, C. J. Power Sources 2013, 236, 250-258. (c) Luo, K.; Roberts, M. R.; Hao, R.; Guerrini, N.; Pickup, D. M.; Liu, Y. S.; Edström, K.; Guo, J. H.; Chadwick, A. V.; Duda, L. C.; Bruce, P. G. Nat. Chem. 2016, 8, 684-691.

(3) (a) Sathiya, M.; Rousse, G.; Ramesha, K.; Laisa, C. P.; Vezin, H.; Sougrati, M. T.; Doublet, M. L.; Foix, D.; Gonbeau, D.; Walker, W.; Prakash, A. S.; Ben Hassine, M.; Dupont, L.; Tarascon, J. M. Nat. Mater. 2013, 12 (9), 827-835. (b) McCalla, E.; Abakumov, A. M.; Saubanere, M.; Foix, D.; Berg, E. J.; Rousse, G.; Doublet, M. L.; Gonbeau, D.; Novak, P.; Van Tendeloo, G.; Dominko, R.; Tarascon, J. M. Science 2015, 350 (6267), 1516-1521.

(4) Tarascon, J. M.; Vaughan, G.; Chabre, Y.; Seguin, L.; Anne, M.; Strobel, P.; Amatucci, G. J. Solid State Chem. 1999, 147 (1), 410-420.

(5) (a) Rouxel, J. Chem. - Eur. J. 1996, 2 (9), 1053-1059. (b) Goodenough, J. B.; Kim, Y. J. Solid State Chem. 2009, 182 (10), 2904-2911. (c) Fong, R.; Dahn, J. R.; Jones, C. H. W. J. Electrochem. Soc. 1989, 136 (11), 3206-3210.

(6) Armstrong, A. R.; Holzapfel, M.; Novak, P.; Johnson, C. S.; Kang, S. H.; Thackeray, M. M.; Bruce, P. G. J. Am. Chem. Soc. 2006, 128 (26), 8694-8698.

(7) Hy, S.; Felix, F.; Rick, J.; Su, W. N.; Hwang, B. J. J. Am. Chem. Soc. 2014, 136 (3), 999-1007.

(8) Koga, H.; Croguennec, L.; Menetrier, M.; Douhil, K.; Belin, S.; Bourgeois, L.; Suard, E.; Weill, F.; Delmas, C. J. Electrochem. Soc. 2013, 160 (6), A786-A792.

(9) Whittingham, M. S. Chem. Rev. 2004, 104 (10), 4271-4301.

(10) Shaju, K. M.; Bruce, P. G. Adv. Mater. 2006, 18 (17), 23302334. 
(11) Larson, A. C.; Von Dreele, R. B. Los Alamos National Laboratory Report 2000, 86-748.

(12) Dent, A. J.; Cibin, G.; Ramos, S.; Smith, A. D.; Scott, S. M.; Varandas, L.; Pearson, M. R.; Krumpa, N. A.; Jones, C. P.; Robbins, P. E. J. Phys. Conf Ser. 2009, 190, 012039.

(13) Ravel, B.; Newville, M. J. Synchrotron Radiat. 2005, 12, 537541.

(14) (a) Nordgren, E. J. J. Electron Spectrosc. Relat. Phenom. 1996, 78, 25-30. (b) Nordgren, J.; Wassdahl, N. J. Electron Spectrosc. Relat. Phenom. 1995, 72, 273-280.

(15) Stöhr, J. NEXAFS Spectroscopy; Springer, 1992.

(16) Peng, Z. Q.; Freunberger, S. A.; Chen, Y. H.; Bruce, P. G. Science 2012, 337 (6094), 563-566.

(17) Chen, Y.; Freunberger, S. A.; Peng, Z.; Barde, F.; Bruce, P. G. J. Am. Chem. Soc. 2012, 134 (18), 7952-7957.

(18) (a) Meng, Y. S.; Ceder, G.; Grey, C. P.; Yoon, W. S.; Jiang, M.; Breger, J.; Shao-Horn, Y. Chem. Mater. 2005, 17 (9), 2386-2394. (b) Jiang, M.; Key, B.; Meng, Y. S.; Grey, C. P. Chem. Mater. 2009, 21 (13), 2733-2745. (c) Koga, H.; Croguennec, L.; Mannessiez, P.; Menetrier, M.; Weill, F.; Bourgeois, L.; Duttine, M.; Suard, E.; Delmas, C. J. Phys. Chem. C 2012, 116 (25), 13497-13506.

(19) Li, J.; Shunmugasundaram, R.; Doig, R.; Dahn, J. R. Chem. Mater. 2016, 28 (1), 162-171.

(20) (a) Freunberger, S. A.; Chen, Y. H.; Peng, Z. Q.; Griffin, J. M.; Hardwick, L. J.; Barde, F.; Novak, P.; Bruce, P. G. J. Am. Chem. Soc. 2011, 133 (20), 8040-8047. (b) Mizuno, F.; Nakanishi, S.; Kotani, Y.; Yokoishi, S.; Iba, H. Electrochemistry 2010, 78 (5), 403-405.

(21) Ito, A.; Sato, Y.; Sanada, T.; Hatano, M.; Horie, H.; Ohsawa, Y. J. Power Sources 2011, 196 (16), 6828-6834.

(22) (a) Hy, S.; Su, W. N.; Chen, J. M.; Hwang, B. J. J. Phys. Chem. C 2012, 116 (48), 25242-25247. (b) Yoon, W. S.; Balasubramanian, M.; Yang, X. Q.; Fu, Z. G.; Fischer, D. A.; McBreen, J. J. Electrochem. Soc. 2004, 151 (2), A246-A251.

(23) Simonin, L.; Colin, J. F.; Ranieri, V.; Canevet, E.; Martin, J. F.; Bourbon, C.; Baehtz, C.; Strobel, P.; Daniel, L.; Patoux, S. J. Mater. Chem. 2012, 22 (22), 11316-11322.

(24) Strobel, P.; Lambertandron, B. J. Solid State Chem. 1988, 75 (1), 90-98.

(25) (a) Gu, M.; Genc, A.; Belharouak, I.; Wang, D. P.; Amine, K.; Thevuthasan, S.; Baer, D. R.; Zhang, J. G.; Browning, N. D.; Liu, J.; Wang, C. M. Chem. Mater. 2013, 25 (11), 2319-2326. (b) Fell, C. R.; Qian, D. N.; Carroll, K. J.; Chi, M. F.; Jones, J. L.; Meng, Y. S. Chem. Mater. 2013, 25 (9), 1621-1629.

(26) Saubanere, M.; McCalla, E.; Tarascon, J.-M.; Doublet, M.-L. Energy Environ. Sci. 2016, 9, 984-991. 